\title{
Fair Value Accounting on the Housing Crisis
}

\author{
Phillip Neely $\mathrm{Jr}^{1}$, Ray Muhammad ${ }^{2}$ \\ ${ }^{1}$ Ph.D., Associate Professor of Criminal Justice, Saint Leo University, USA, 404-392-6200 \\ ${ }^{2}$ MBA, Adjunct Professor of Business, Saint Leo University, USA, 404-392-6200 \\ Correspondence: Phillip Neely Jr, Ph.D., Associate Professor of Criminal Justice, Saint Leo University, USA, \\ 404-392-6200
}

Received: June 24, 2016 Accepted: July 12, $2016 \quad$ Online Published: July 20, 2016

doi:10.11114/bms.v2i3.1755

URL: http://dx.doi.org/10.11114/bms.v2i3.1755

Program Track: Accounting

\begin{abstract}
The circumstances which led to the development of each of these methods of accounting will be examined to better understand the context in which each technique was to be incorporated and its effect. Analysis will be performed on whether the use of these accounting practices changed since their inception and if so, for what purpose. The researcher will discuss how and if these accounting procedures become instrumental in relation to the valuation of housing assets, particularly in America. As a result of the financial crisis, some experts have expressed the opinion that Fair Value Accounting as opposed to the historical cost approach exacerbated the housing crisis while others have developed opinions that Fair Value Accounting had no negative affect on the crisis and in fact allowed for greater transparency in disclosure. The finding will analyze the effect of Fair Value Accounting on the housing crisis and whether the historical cost valuation method would be more effective and less subject to risk in home asset valuation by bank holding companies. Research findings will determine which method is most effective and whether an alternate model of valuation would provide a more reliable accounting practice for the housing market.
\end{abstract}

Keywords: fair value accounting approaches, security review, correlation \& statistical analysis

\section{Introduction}

Accounting has played a role in transactions among human beings more than likely since the beginning of time. The Bible stories often record loss and gain in a form that is clearly based on record keeping and reconciliation. Additionally, there are numerous references to principles supply and demand, census and taxation which are synonymous to theories of accounting. History records the Zenon, the Greeks and Egyptians, all having some form of accounting procedure. According to Schroeder, Clark, \& Cathey (2011), many of these systems were quite complex and included records of employee wage, inventory, accruals, profit and loss as well as asset management tools to show how well or poorly the company performed during a given period. Much like government officials of today, kings, governors, and religious leaders used theories of accounting thousands of years ago to forecast and track the condition of the community based on the concepts of supply and demand and profit and loss. Similar to today's Chief Executive Officers (CEO), business owners of ancient times considered expansions, mergers, and even hostile takeovers and the success of these decisions required a thorough knowledge of the debt to income ratio of their holding. The ability to accurately communicate the fiscal reality of the company was important to prospective partners and critical to business men so they could make sound decisions.

Any group seeking to conduct business with others would need to keep records that were easy to read and clearly stated. As the Italians sought to become more involved in commerce, they came to recognize the need for some measure of consistency, and in 1494, Fra Luca Pacioli, referred to by many as the father of accounting, penned a book entitled, Summa de Arithmetica Geometria Proportiomniet Proportionalita which although according to Schroeder et al (2011)

did not offer a comprehensive understanding of double book keeping; it did familiarize the reader with the general concept as a standard method of business recording, which enabled entities to prepare financial statements.

These statements offered a general disclosure of corporate transactions and gave an idea of the activity of a company but they were still not detailed enough to provide and true forecast of the condition of the company at any given time. 
Certain aspects such as capital were emphasized while other vital business components such as expense and income were considered random as reported by Schroeder et al (2011).

\subsection{Historical Cost Accounting}

The practice of various forms of cost accounting was implemented more purposefully during the 1800 s. King, Premo \& Case (2009) surmise that the rise in prominence of these practices can be mapped directly to the military academies of the United States. Few organizations employed a greater number of people, utilized such a vast amount of supplies, and projected and coordinated movements across the entire country with the precision and versatility of the United States military. Additionally, no group could say their success or failure imminently depended on accurate forecasting as the United States military.

For centuries military commanders including Alexander the Great, Hannibal, Sun Tzu, Nappoleon, and Julius Ceasar have studied and written about the importance of being able to properly care for and equip their soldiers to successfully fulfill the important missions set before them. Military leaders in the U.S. armed forces studied these theories of warfare and refined tactics to make their military more successful. Although bookkeeping played a role in the success of the military, even successful commanders such as General George Washington were unable to account for large sums of money that were identified as lost, stolen or paid away without charging." (Palmer, 1976)

These types of shortfalls made obvious the deficiencies of the current system of record keeping. Not only did the failure to account for income amounts represent a massive fiscal loss to the military, it affected morale because wages were many times misallocated and critical supplies failed to arrive as scheduled which led to the untimely demise of many soldiers. This was a major cause of concern and led to the development of what would be known as "scientific management" to be taught at military institutions as well as implemented as a part of the military protocol according to King, et al (2009) who also states this new brand of management, popularized under the leadership of Colonel Sylvanus Thayer while acting as superintendent of the United States Military Academy would propel the United States into the role of front runner in the evolution of cost and management accounting.

Although this complex accounting system facilitated accurate disclosure of the salary and material cost expenses associated with military operation, the budget and inventory reports precipitated based on actual historical expenditures would prove invaluable. Accurate budget reports allowed military commanders to provide accurate estimations to congress for approval of military spending budgets for the upcoming year as well as identify areas for research and development based on weaknesses identified as a result of recorded transactions and the rationale behind their existence. Inventory reports are extremely important to military organizations and aide in the development of budget reports and requests. Inventory not only provides understanding of what material is on hand, it allows military leaders to value what has nearly reached the end of its typical life cycle and prepares to replace. Inventory reports offer insight into how prepared the military is for defense and for what amount of time in what area of the earth. In order to be properly prepared to repel all threats foreign and domestic, the military must have a sufficient inventory to mobilize and sustain itself in any terrain and climate.

\subsection{Accounting and Education}

The introduction of the military's managerial practices into the business world caused reflection and introspection. Businesses acknowledged a need for training in these methods, discerning that effective cost accounting could provide valuable financial benefit. According to Wyhe (2007), the belief that financial expertise could be achieved through education was realized in 1881. John Wharton established the first school of Business at the University of Pennsylvania with a stipulation that staff include a teacher of accounting or bookkeeping. By 1887, the American Institute of CPAs (AICPA) reveals that the American Association of Public Accountants was created with the purpose of implementing rules and regulations as well as establishing criterion designed to advance the accounting profession. As King, et al (2009) points out, a major focus of the newly materialized organization was the academic programs offered to accounting students. The University curriculum was considered a vital component in producing professional public accountants and those in the profession sought to ensure those entering the field would be well prepared. In a short time, several Universities began introducing Accounting 101 courses to teach accounting and bookkeeping methods. These courses were taught from a practical perspective of the public accountant but offered little in the way of theoretical application. This direction was disturbing for scholars of liberal arts universities according to Whye (2009). Soon the conflict between the offering coursework covering the mechanics of accounting as opposed to theoretical application would provide rationale for much debate.

The criterion for early accounting coursework was dominated by certified public accountants. As King, et al (2009) points out, the State of New York established the title of Certified Public Accountant requiring accountants to pass a state exam to attain certification. With the additional prerequisite requirement that applicants have a college education, schools were left with little option but to teach accounting practices which would prepare students for the exam and a 
career in public accounting based on general input from the American Institute of Accountants (AIA). Accordingly, the practice of accounting would be learned rote in accordance with the philosophy espoused by the father of management, Frederick Taylor who said management is best learned through habitual repetition. Students would learn the practices that had been established in the field of public accounting and apply them systemically as opposed to via analyses designed to question when and if current practices were optimal or if there were better systems to be developed. While this was satisfactory to practitioners who were the primary people fulfilling the role of educator, other academics felt the methodology was insufficient and many opposed what they felt was overarching influence by the AIA.

Academics sought to establish private accountants as "professionals" much the same as were public accountants. Although they performed of their accounting duties was different, it was no less important and was no less stringent. The private accountant was perhaps the greatest ally of management while the public accountant was completely autonomous. An article in The Accounting Review defined professional accountant to include, "the work of internal accounting and auditing as well as the professional practice of the independent public accountant". (Smith, 1945, 17). This declaration effectively began opened a path for industrial accounting and public accounting methodologies to be taught on the college level, according to King, et al (2009). This new direction created the opportunity for many types of private accounting concentrations to be developed. Scholars and practitioners were forced to explore the essence of accounting and examine whether accounting was an immutable science or an ever evolving art? By scrutinizing the purpose of accounting, this answer as well as others could provide insight into the direction of the field of accounting.

Based on questions such as what purpose was served by accounting reports and who were the primary users, managerial accounting arose to join financial accounting practices espoused by public accountants. Although originally perceived to be diametrically opposed, these practices would one day serve to compliment one another. Managerial accounting took into account the concerns of management while financial accounting provided financial data for those outside the company such as shareholders. The purpose of managerial accounting was to allow management to take into account current and projected financial conditions so that managers were able to make well informed business projections and decisions for the corporation. Mowen and Hansen's adequate description referenced by King, et al (2009) that one of the primary purposes of cost and managerial accounting is to allow stewards to assess the cost versus the benefits of resources to make well informed decisions, maximizing the organization's return on investment. Financial accounting provided accounting data to shareholders so interested parties could make determinations in reference to the health of the company. Public accountants welcomed the development of managerial accounting and utilized its principles as they became more involved in corporate management processes as consultants. Academics were excited to be able to offer a course framework which provided a broader education.

Accountants were no longer thought to be "pencil pushers." Increased participation with management and greater involvement in the decision making process meant accountants not only needed to be able to record numbers, accountants now had to be able to effectively communicate the meaning of these figures. As a King, et al (2009) describes, Gordon and Howell described in their 1959 report for the Carnegie Corporation, that business and accounting programs could only fulfill these needs by becoming less of a vocational training and more mentally stimulating.

\subsection{Fair Value Accounting}

Fair Value Accounting (FVA) is defined in the Statement of Financial Accounting Standard No. 157 as "the practice of declaring the value of the asset or liabilities." Originally, Fair Value assessment was based on the exit price or price a participant could command for an asset when selling the asset. However, this standard was proved less than ideal because most times, a person or company who does not specialize in the sale of a product does not receive the same price as an individual or company who routinely is in the sales business. In an ideal situation, there is an abundance of market activity in which identical assets are traded. This will provide the accountant a pool of transactions which are current and identical, allowing for an accurate valuation. For less active markets with few comparable sales, analysis requires more hypothetical and extraordinary assumption which may be less reliable. Accountants are forced to seek sales of similar assets or use indexes which may provide good general information but fail to account for certain specific and critical characteristics of the asset valuation by the accountant. If the assumptions prove incorrect, the cost to the company as well as investor could be major and in some instances catastrophic.

Fair Value Accounting is widely accepted and evidence supports its effectiveness when some accounting conditions are present. Active markets with an adequate number of recent arm's length transactions provide valuable information for analysts. Scrutinies of comparable sales offer insight into reasonable estimates of value for similar assets in the open market. In instances such as valuation of real estate holdings, this analysis provides internal and external parties a stock index like resource which considers current market forces and environment. For less active markets with few comparable sales, analysis requires more hypothetical and extraordinary assumption which may be less reliable. If the 
assumptions prove incorrect, the cost to the company as well as investor could be major and in some instances catastrophic.

The concept of Fair Value Accounting became more prominent in the 1960s as a result of the issuance of Accounting Research Study (ARS) No.3 by the Accounting Research Division (ARD). In this statement the Accounting Principles Board (1962) iterated changes in asset valuation should be recognized whenever it is possible to do so objectively. The American Accounting Association issued "A Statement of Basic Accounting Theory" which listed the purpose of financial information to be communication, according to Emerson, Karim and Rutledge (2010). The document went on to emphasize the importance of "relevance" in financial reporting; implying a key element of valuation was the most current market value as opposed to historical cost. Other committees continued to endorse this accounting position which solidified FVA in accounting framework.

\subsection{Fair Value Accounting and the Housing Crisis}

Many people were affected by housing crisis of 2007 described by many as the most devastating financial disaster of our lifetime. Popular opinion suggests that during the mortgage crisis, FVA played a major role in the valuation of securities backed by subprime mortgages. However, some scientists suggest that the Fair Value Accounting method itself was not to blame for the crisis. They point to certain companies which implemented FVA and were not devastated by the Crisis. Also, some scientists say Fair Value Accounting was not a commonly used accounting practice and therefore could not have had a large effect on the market outcome. Whether Fair Value Accounting was a primary contributor to the Crisis may be debated. What is indisputable is there were many other factors present to produce such catastrophic affects.

FHA rules required marketable securities to reflect market values regardless to whether the holder had an intention of selling in the foreseeable future. Therefore, mounting foreclosures led to devaluation of mortgage backed securities. As these securities seemed to be in severe decline, consumer confidence fell and demand became nonexistent. As a result, the mortgage backed securities that were to be sold were constantly reduced and sold for loss causing lenders to call in loans further distressing the market and creating an ongoing "fire sale". According to some accounting practitioners, this downward spiral would not have occurred had historical cost accounting values been used on these securities.

These scientists believe much of the blame placed on Fair Value Accounting is misplaced as a result of lack of knowledge of regulation. According to Laux and Leuz (2013), research does not focus enough on whether banks were using market prices voluntarily based on private arrangements or whether they were using required market values. Additional issues raised by Laux and Lues (2013) are: what percent of Fair Value changes were placed on the companies' balance sheets and because they differ in regulation, how much of what is attributed to Fair Value Accounting is in fact, pure Mark-to-Market accounting?

\section{Literature Review}

Securitization was developed in the 1970s and quickly became an essential practice for secondary investment in the residential mortgage industry. These securities became widely known as Mortgage Backed Securities (MBS) and became a central component of the eventual housing crisis. Investment banks used this tool increasingly to create leverage, becoming more and more dependent on MBS until foreclosures led some of these powerful banks to fail. In this study, Adhikari and Betancourt (2008) examine two critical elements of securitization: de-recognition and consolidation. The authors point out the growing use and importance of securitizations and how their use affects finance ratios. Reviewing the Ford Company, Adhikari and Betancourt analyze sales securitization transactions and borrowing securitizations to analyze the effect of these transactions on the corporation's leverage.

The following diagram illustrates the basic premise of securitization:

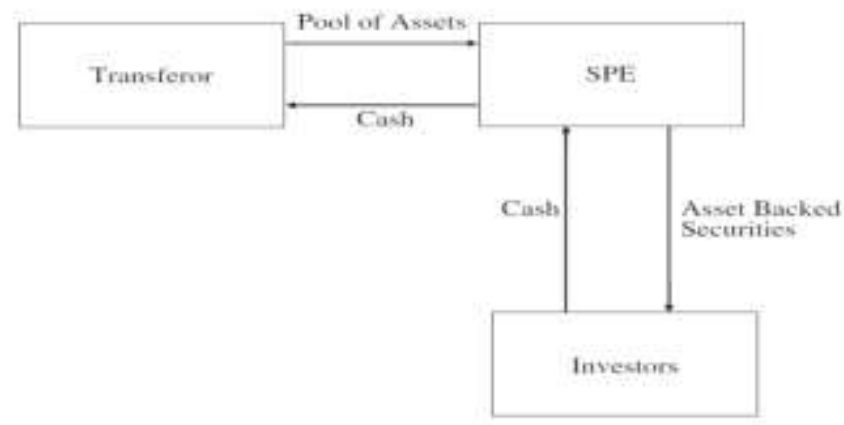

Figure 1. Diagram of Simple Securitization 
Figure 1 presents a simplified diagram of a typical securitization. In Figure 1, the owner (transferor) of a pool of assets transfers the pool of assets to a special purpose entity (SPE), which can be a trust or corporation. The SPE issues ownership interests (asset backed securities) in the cash flows from the pool of assets to investors in exchange for cash. The cash received by the SPE from the investors is transferred to the transferor as payment for the pool of assets. During the life of the assets, the cash flows generated from the loans are collected on behalf of the SPE by a servicing agent, oftentimes the transferor, and then passed on to the investors. (Adhikari and Betancourt, 2008)

Securitizations may either be de-recognized as a sale or as secured borrowing using two established techniques: 1) the predominant-characteristic paradigm (also known as the risk and rewards) approach, in which the determination of whether the asset is considered to have been sold depends on whether the majority of the associated risks and rewards are retained by the transferor and 2) the financial components paradigm (referred to as the control) approach where assets may be divided into multiple components and the level of de-recognition correlates to the amount of control surrendered by the transferor. Securitization transactions which are considered sales are preferable to secured borrowings because the sale allows the transferor to record a gain from the sale while removing the liability from the entity's books. A secured borrowing is less appealing because the transferor must maintain the account receivable on the books in addition to the liability plus interest associated with the loan. Therefore, regulatory requirements for which transactions may be considered a sale and why they are a critical element of securitization which is a major component of today's business practices.

In their study, Adhikari and Betancourt (2008) study "the differences in accounting results for the same accounting securitization transaction" as recorded under the guidelines of US GAAP versus IFRS. The results of the study indicate there are likely material differences as a result of each of these two reporting standards. Consequently, as US regulations allow larger amounts of assets to be classified as sales transactions, they are removed from balance sheets allowing companies to record a more advantageous leverage ratio. Additional leverage while beneficial, allows companies to amass higher debt possibly making them vulnerable to collapse.

The authors assessed the percentage of securitized transactions made by several major automotive corporations. While the study dealt specifically with an automobile corporation, the authors acknowledge the effects are probably similar across industries ranging from manufacturing to financial corporations. This is significant for research because most scientists believe leverage practices by financial firms contributed significantly to the housing crisis of 2007.

Allen and Carletti (2010) identify three specific market failures: 1) inefficient liquidity procedures 2) mispricing of assets due to limits to arbitrage and 3) contagion. In times of failure, central banks may provide liquidity to prevent companies from collapse. To address liquidity issues, countries such as Chile have a government controlled central bank in addition to private banks which seeds emergency funds to financial service entities in times of crisis. This is designed to prevent large collapses such as what was experienced in the United States. Essentially the U.S. Government was forced to fulfill this role by offering $\$ 700$ billion in aid to prevent a near total collapse of the banking system during the housing crisis. Allen and Carletti (2010) suggest this government action should be mandated by regulation as opposed to requiring a vote by the corporate board.

In order to address price volatility and arbitrage, the composers suggest further research to determine the cause of the volatility. Of course, mark to market accounting is hotly debated to be a factor in limiting arbitrage. However, consideration must be given to ways to prevent such an occurrence. Allen and Carletti (2010) believe when model and market prices differ more than a set level, both should be published. By disclosing both figures to all parties for consideration in decision making, the authors believe market volatility will be reduced.

Future research in this area should consider how hedge accounting disclosures help investors and corporations. Also research must be performed to determine whether early recognition actually reduces volatility and if so, does fair value accounting have the same effect in general accounting? Why or why not? Lastly, has SFAS 133 reduced the frequency with which corporations experienced large losses due to derivative trading? If not, should there be adjustments to SFAS 133 ?

McMahon teaches the reader SFAS 133 was introduced to disclose potential losses by corporations. However, she questions the ability of SFAS to allow companies to add large sums of money to their balance sheets as a result of mark to market figures. Additional concern is raised because of how SFAS 133 allows hedge accounting to be used to smooth earnings. Additionally, the implementation of SFAS 133 leads managers to use greater discretion reporting loan loss provisions.

McMahon makes several contributions to research. The first important suggestion she makes is a greater concentration of research into Level II as opposed to Level III assets. McMahon insists Level II is the primary where unrecognized gains as a result of derivatives trading hide in plain sight. While she does not espouse historical cost accounting as an end all be all to solving the issue of valuation, she believes it removes some of the volatility presumed to be associated 
with mark to market accounting. McMahon (2011) also suggests US GAAP and IFRS re-evaluate the ability for unrealized gains to be moved to equity as they are unrealizable.

McMahon (2011) suggests future research be conducted into the behavioral aspect of investors, managers and corporate risk appetites during times of economic upturns. Did the appetite for risk increase because of the sense of financial stability? If so, did this increased appetite also cause managers to ignore signs of decline or cause them to stick with investments longer? McMahon (2011) identifies factors such as momentum,

Another concern is: are there alternatives to recording mark to market quarterly or at the time of transaction for equity reporting? Would averaging mark to market valuations over a period of 1 to 5 years make valuations less susceptible to market volatility? Would the average over a longer period provide accurate accounting for investors who may specialize in short term investment for gains?

Milbradt effectively examines the trading behavior of banks in reference to Level 3 assets. The writer determines when banks suspend trading and when it is typically resumed. Milbradt writes, that institutions "optimally balances the benefit of a relaxed balance sheet constraint against the cost of possible excessive exposure to determine when to stop and restart trading, and thus when to book gains and losses, and if to follow such no trading strategy at all." (Milbrasdt, 2012) This offers great value in understanding how fair value accounting and bank behavior may cause inaccurate asset valuation which could make financial markets susceptible to crisis conditions.

Based on the literature, accounting evolved over thousands of years. Prior to 1929 there were few standards of accounting which some attribute to the great stock market crash. A lack of standards led to inconsistent reporting and complete omission of many elements of financial reporting that would be considered critical for surmising corporate financial condition by today's standards. Additionally, because there were no standard procedures, reports were not reliable because there was little rationale perspective provided to provide financial perspective. After the stock market collapse of 1929, the accounting became regulated with the origination of the Securities and Exchange Commission. Historical cost accounting was the predominantly used method of accounting, followed more recently with fair value accounting which gained traction in 1962 upon the release of Accounting Research Study No. 3. Accounting Research Study 3 calls into question the effectiveness of maintaining a historical value if current values are able to be measured, according to Emerson, Karim and Rutledge (2010). Following this writing, the American Association of Accountants sought a more comprehensive accounting theory which embodied four standards: relevance, verifiability, impartiality and quantifiability as reported by Emerson, Karim and Rutledge (2010).

Fair value accounting would not be implemented for fifty years. When the Accounting Research Division issued ARS 3 recommending the use of fair value accounting, the concept was considered too extreme even by its parental board, the American Institute of Certified Public Accountants (AICPA). According to Emerson, Karim and Rutledge (2010), the Institute to declare that a move to fair value would be too radical to become a "generally accepted" accounting practice. Eleven years later, the Trueblood Committee asserted that a single valuation method was not comprehensive enough to be sufficient for users. The Wheat Committee and others reaffirmed this opinion and in 1984, FASB issued a statement requiring the use of fair value accounting, progressively heightening its use with successive statements. Although the SEC was slow to move toward fair value accounting, they realized this method to be more relevant to investors and seemingly better for all parties to recognize the financial condition of corporations.

By 1993, when the FASB issues its Statement 115 on accounting for investments which espouses fair value accounting, in a change from their long held position on fair value accounting, the SEC advocates but banks staunchly oppose this move according to Zeff (2005). They assert fair value accounting is inferior due to its associated earnings volatility. Zeff reports "trading Securities" and "available for sale securities" are both recorded on balance sheets using fair value accounting and unrealized earnings and losses are recorded as shareholder equity as opposed to earnings. This arrangement for balance sheets and more importantly the mark to market valuation method would become the cornerstone of debate as a cause of the housing crisis of 2008 and an area of study for the author. The application section will attempt to syncretize the views of normative and positive theory proponents and strike a balance that may lead to a more effective method of accounting for securities and equity.

The critical debate between the use of historical accounting versus fair value accounting as an effective tool for preventing the recurrence of a crisis similar to that of 2008 appears best resolved through historical analysis. The question is not simply whether historical accounting is a viable alternative to fair value accounting for relevant record keeping? During the Savings and Loans crisis, historical accounting was the prominent accounting method and it was acknowledged to have exacerbated the crisis at that time. According to Seay and Ford (2010), the declining financial condition of corporations was ambiguous because historical accounting mummified asset values that were in fact collapsing. Therefore, historical accounting failed to signal pending catastrophe even if the concern was overstated as is thought to occur with fair value accounting. Consequently the critical question, as opposed to whether to use historical accounting is what improvements can be made to fair value accounting so it is more effective. 


\section{Methodology}

Based on studies by legislative bodies, inflated appraisal valuations were thought to be a major factor of the subprime explosion. In many instances, estimated values by appraisers appeared to be influenced by contract prices that had been agreed upon by the buyer and seller in a market transaction prior to the lender ordering the appraisal. Further review seems to indicate that appraisers may have been influenced by the contract as well as pressure from the lender to reach a certain threshold in order to avoid contract failure due to unsupported value. This conflict of interest appears to have had a great influence in lending; as a result, legislation was implemented to address these conflicts of interest according to Ding and Nakamura (2014).

The HVCC removed the direct influence of lenders from the valuation process. The intention was to facilitate a completely unbiased valuation and eliminate backlash from lenders if a desired value was not supported by market data. Hopefully this new valuation method would provide market consistency and stability as opposed to facilitate rapid price increases and market bubbles. Ding and Nakamura (2014) discovered there were reduced levels of overvaluation as a result of the HVCC. Additionally, the researchers found a higher incident of low appraisals; instances where the estimated value was lower than the agreed upon contract price. The writers suggests that this low valuation made obtaining loans more difficult, however in most instances of non-supported value, both parties agree to reduce price or amend other terms of the contract to facilitate the sale. The lower valuation many have less impact than the data would suggest and further analysis into how many sales are ultimately achieved despite the low valuation as well as its accuracy based on market data in needed.

\section{Conclusion}

Corporations already have enough instruments available to them so that fair value accounting would not be significant to a housing crisis. Additionally, if the tendency is to overvalue similar to appraisers, corporations would likely have overvalued commodities even during crisis as reported by Laux and Leuz (2009). Perhaps the same or similar mechanisms used in housing appraisals should be used for mark to market. Fair value assessments made by corporations must be independent. It is possible, different third party companies should make the valuation independent of the client for which the valuation is needed. If the third party accounting firm is not aware for whom the appraisal has been ordered, there should be no bias. Since these valuations were actually a small part of the industry overall, the costs should not be unbearable and certainly more tolerable than the alternative losses as a result of inaccurate valuations.

Researcher Dale Skinner writes, "The economy has changed in such a way that conventional financial statements have become less relevant." (2008, Skinner) As such, the way we account for a bevy of unique products must be performed so that there is a balance between what the owner sees as compared to external users of the product. As an owner invests in items for and around the home that appeal to them, businesses who make a commitment to commodities believe these items have great. Just as an owner expects a dollar for dollar return for the investments they believe are "upgrades" to the home, corporations depend on a similar return. The market may not agree; the appraiser is the independent party to verify or not, the presence of value. Similarly, a third party accountant firm should verify the value or not, for corporate commodities that are difficult to appraise. This action should also be entered into a data base so that even when sales are sparse and spread over a long period of time, the data bank will be able to analyze the newly estimated value and compare it to market conditions as well as previous sales and signal red flags that may not be obvious to the auditor using only current and local data.

Implementing these procedures should be more beneficial to investors and other users than the current practices. Although fair value accounting readily provides accurate pricing points in markets plentiful with sales, accurate pricing is difficult in markets with limited or no recent sales of similar commodity. Additionally, investors are able to cross reference fair value estimations on balance sheets by cross referencing other companies' figures in active markets. However when market transactions are scarce, the current system of accounting does not offer external sources to support estimated values or provide some audit to validate that the rationale used is sound, thereby boosting investor confidence.

The measures suggested in the Application section should be considered and researched as viable mechanisms for accounting in the future. Cost efficiency should be researched so corporations are not burdened with excessive expense in order to ensure accurate valuation. Additionally, the industry and regulators must strike a balance between governance and free market enterprise. The litmus for where the balance should lie is with the public interest. The author looks forward to researching these possibilities in the future.

\section{Author Information}

Dr. Phillip Neely is the recipient of the Doctor of Philosophy in Public Policy and Administration from Walden University and the Masters of Science in Public Administration from Central Michigan University. He is an Associate 
Professor at Saint Leo University in Duluth, Georgia. Dr. Neely's expertise comes in the field of criminal justice and public policy.

Ray Muhammad is the recipient of the Masters of Science in Accounting from Walden University and Bachelors in Sociology from Florida State University. He is an Adjunct Professor at Saint Leo University in Duluth, Georgia. Ray Muhammad's expertise comes in the field of accounting and business management.

\section{References}

Adhikari, A., \& Betancourt, L. (2008). Accounting for Securitizations: A Comparison of SFAS 140 and IASB 39. Journal of International Financial Management \& Accounting, 19(1), 73-105. http://dx.doi.org/10.1111/j.1467-646X.2008.01017.x

Allen, F., \& Carletti, E. (2010). An Overview of the Crisis: Causes, Consequences, and Solutions. International Review of Finance, 10(1), 1-26. http://dx.doi.org/10.1111/j.1468-2443.2009.01103.x

Ding, L., \& Leonard, N. (2014). The Impact of the Home Valuation Code of Conduct on Appraisal and Mortgage Outcomes. Federal Reserve Bank of Philadelphia, Working Paper 14-23.

Jeanjean, T., \& Ramirez, C. (2009). Back to the Origins of Positive Theories: A Contribution to an Analysis of Paradigm Changes in Accounting Research. Accounting In Europe, 6(1), 107-126. http://dx.doi.org/10.1080/17449480902896510

Laux, C., \& Leuz, C. (2009). Did Fair Value Accounting Contribute to the Financial Crisis? Journal of Economic Perspectives, 24(1), 93-118. http://dx.doi.org/10.1257/jep.24.1.93

Laux, C., \& Leuz, C. (2013). The crisis of fair-value accounting: Making sense of the recent debate. Accounting, Organizations and Society, 34(6-7), 826-834. doi.org/10.1016/j.aos.2009.04.003

McMahon, G. (2011). Mark-to-Market's Real Role in the Crisis. CPA Journal, 81(2), 46-55.

Milbradt, K. (2012). Level 3 Assets: Booking Profits and Concealing Losses. Review of Financial Studies, 25(1), 55-95. http://dx.doi.org/10.1093/rfs/hhr112

Palmer, J. R. (1976). The Revolution Was Not in Accounting. Tempo, 22, 19-23.

Schroeder, R., Clark, M., \& Cathey, J. (2011). Financial Accounting Theory and Analysis: Text and Cases, 10th Edition.

Seay, S. S., \& Ford, W. H. (2010). Fair Presentation—an ethical perspective on Fair Value Accounting pursuant to the SEC Study on Mark-to-Market Accounting. Journal of Legal, Ethical \& Regulatory Issues, 13(1), 53-66.

Skinner, D. J. (2008). Accounting for intangibles - a critical review of policy recommendations. Accounting \& Business Research (Wolters Kluwer UK), 38(3), 191-204. http://dx.doi.org/10.1080/00014788.2008.9663332

Wallison, P. (2011). The Lost Cause: The Failure of the Financial Crisis Inquiry Commission. Retrieved from American Enterprise Institute.org

Zeff, S. A. (2005). The Evolution of U. S. GAAP: The Political Forces Behind Professional Standards. CPA Journal, 75(2), 19-29.

\section{(c) EY}

This work is licensed under a Creative Commons Attribution 3.0 License. 